PONTIFÍCIA UNIVERSIDADE CATÓliCA DO RIO DE JANEIRO

\author{
MOTIVAÇÃO EMPREENDEDORA: \\ O QUE MOTIVA OS JOVENS ORIUNDOS DE \\ CAMADAS POPULARES A EMPREENDER?
}

André Luís Regis da Silva

Trabalho de Conclusão de Curso

Centro de CiênCIAS SOCIAIS - CCS

DEPARTAMENTO DE AdMINISTRAÇÃo

Graduação em Administração de Empresas 


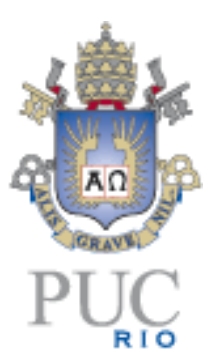

André Luís Regis da Silva

\title{
Motivação Empreendedora
}

O que motiva os jovens oriundos de camadas populares a empreender?

\author{
Trabalho de Conclusão de Curso
}

Trabalho de Conclusão de Curso, apresentado ao programa de graduação em Administração da PUC-Rio como requisito parcial para a obtenção do título de graduação em Administração.

Orientadora: Mila Desouzart de Aquino Viana

Rio de Janeiro,

Novembro de 2021. 
"Pode pedir

Você vai encontrar

Peça pro céu, pro mar

Teu sonho escondido

Pode pedir

Você vai renascer

Quando amanhecer

Teu sexto sentido

No futuro você vai ser feliz

Pode crer foi teu destino quem quis

$\mathrm{Na}$ beleza da flor

Você vai encontrar seu amor

No futuro você vai ser feliz

Pode crer foi teu destino quem quis

Deixa o tempo passar

Você vai descobrir seu lugar

É bom sonhar

Pra ver o mundo mais bonito

É bom sonhar

O teu desejo é infinito

É bom sonhar

A vida é um tesouro

De sonhos pra conquistar

A esperança existe

E nunca vai acabar

Xuxa: O que você quer ser quando crescer? Qual é seu sonho?

Criança: Eu quero ser médica de bicho!

Xuxa: E você?

Criança: Eu? Eu queria ser professora!

Xuxa: E você?

Criança: Ah eu queria ser igual minha mãe!

Xuxa: E você?

Criança: Ah eu quero ser modelo!

Xuxa: E você?

Criança: Ham...eu quero ser aeromoça!

Xuxa: E você?

Criança: Eu...eu quero ser igual ao meu pai!

Xuxa: E você?

Criança: Eu? Quero ser igual você!

Xuxa: E eu quero ter uma baixinha igual você!'”

(Composição: M. Sullivan / Aloysio Reis Intérprete: Xuxa) 


\section{Agradecimentos}

À Deus, primeiramente. Sem Ele eu não teria conseguido, pois foi o meu alicerce para prosseguir a caminhada.

Aos meus pais Maria e Geraldo, que são a base de tudo, principalmente, minha mãe Maria, que nunca deixou faltar recursos para eu estudar. EU SEI QUE EU SOU SEU ORGULHO!

À tia Graça que sempre me apoiou e se preocupou com os meus estudos. Além de oferecer inúmeros suportes financeiros indispensáveis.

Aos meus amigos universitários: Roberta, Pedro Renato, Marcelo, Maria Laura, Daniela, Steve, Manoella, Beatriz, Danielle, Ricardo, entre outros que fizeram parte da caminhada.

Aos meu professores: Lygia Magacho, Ana Claudia Pinheiro, Edmundo Eutrópio, Eliana Giambiagi, Anna Sotero, Alessandra Baiocchi, Bel Guimaraes, Lea Mara, Roberto Uchoa, Marcus Hemais, Barbara Levy, Luís Pessoa, Marcelo Ghiaroni, Patrícia Itala, Marcos Rego, Alessandra Costa, Luiza Martins, Renata Machado, Marco Aurelio, Sylvia Moraes, Marcos Cohen, Flavia Cavazotte, Rui Marinho, Luís Felipe Carvalho, Patrícia Coralis, Eduardo Pimentel, Ana Paula Santoro, Monica Campos, Marcos Antônio, Regina Sardinha, Andrea Cherman, Marina Frid, Paula Cunha e Marcela Amorim.

À Ana Heloisa por acreditar em mim e apresentar a pesquisa acadêmica no PIBIC e ajudar a construir o meu TCC.

Aos meus irmãos de coração: Maria Julia e Luís Felipe pelo apoio incondicional.

Ao meu namorado, Luís Fernando Rukop, pelo apoio e incentivo na construção final do meu estudo.

Aos jovens estrelas deste TCC: Priscilla, Lidiane, Carina, Jessica, Elizandra, Lorruama, Edilaine, Rodrigo, Vanessa e Andressa.

À Mila, amiga, mãe, madrinha e orientadora deste estudo. Só tenho gratidão por tê-la conhecido e acreditado em meu projeto. Você foi o presente mais especial que a PUC me deu.

E, finalmente, a mim, porque eu fui o protagonista da minha trajetória universitária. 


\section{Resumo}

Silva, André Luís Regis. Motivação Empreendedora: O que motiva os jovens oriundos de camadas populares a empreender. Rio de Janeiro, 2021. 45p. Trabalho de Conclusão de Curso - Departamento de Administração. Pontifícia Universidade Católica do Rio de Janeiro.

O presente estudo visa investigar os fatores motivacionais que levam os jovens da Geração Y e, pertencentes às camadas populares da cidade do Rio de Janeiro, a empreender. Para isso, foi adotada uma metodologia de natureza qualitativa estruturada em um roteiro de perguntas para 10 jovens millennials, empreendedores e oriundos de baixa renda.

O objetivo foi levantar informações através de suas experiências de vida e por meio de seus relatos em suas trajetórias empreendedoras, adicionalmente, procurou-se compreender o quanto à motivação, por vários motivos alheios a esses jovens, é um aspecto importante para decidir abrir um negócio.

Observou-se que não há como generalizar as características geracionais e empreendedoras, quando o aspecto da desigualdade social interfere na vida desses jovens.

Analisando os resultados, observou-se que um número expressivo dos entrevistados empreendeu por necessidade, mostrando-se um importante fator de motivação para esses jovens, como solução para lidar com as dificuldades, com a falta de empregabilidade, de renda e como a única solução possível de sobrevivência.

Palavras-chave

Empreendedorismo. Jovens empreendedores. Perfil empreendedor. Motivação empreendedora. Geração Y. Jovens de camadas populares. 


\begin{abstract}
Silva, André Luís Regis. Entrepreneurship Motivation: What motivates the youth from popular classes to undertake. Rio de Janeiro, 2021. Number of pages, 45. Course Completion Work - Business Department. Pontifical Catholic University of Rio de Janeiro.
\end{abstract}

The present study aims to investigate the motivational factors that lead the Y Generation youth from the working class of the city of Rio de Janeiro, to become an entrepreneur. For this, a qualitative methodology was defined, structured in a script of questions for 10 young millennials, entrepreneurs from popular classes.

The goal was to acquire information through personal experiences on life and on the journey through entrepreneurship. Additionally, we tried to understand how much motivation, for various reasons related to these people, is an important aspect to open a business.

It's observed that there is no way to generalize the generational and entrepreneurial characteristics, when the aspect of social inequality interferes in the lives of these people.

Analyzing the results, it was observed that a significant number of respondents became an entrepreneur out of necessity, proving to be an important motivating factor for these people, as a solution to deal with difficulties, lack of employability, lack of income and as the only solution possible for survival.

Keywords

Entrepreneurship; Young Entrepreneurs; Entrepreneur profile. Entrepreneur motivation; Y Generation; Popular class Youth. 


\section{Sumário}

Agradecimentos

Resumo

Abstract

1. O tema e o problema de estudo

1.1. Introdução

1.2. Objetivo Principal

1.3. Objetivos Intermediários 3

1.4. Delimitação do estudo 4

1.5. Justificativa e relevância do estudo 4

2. Referencial Teórico 6

2.1. Geração Y 6

2.1.1. Caracterização dos anseios profissionais dos jovens da geração Y 6

2.2. Características empreendedoras $\quad 7$

2.3. Motivação empreendedora

2.3.1 Por necessidade 8

2.3.2. Por oportunidade 9

2.4. Empreendedorismo no Brasil 10

2.5. Jovens de Baixa Renda no Brasil 11

3. Metodologia 12

3.1. Tipo de pesquisa 12

3.2. Seleção dos entrevistados 12

3.3. Coleta de Dados 13

3.4. Análise dos dados 14

$\begin{array}{lc}3.5 \text { Limitações do método } & 14\end{array}$ 
4. Análise e Discussão dos Resultados 16

4.1. Perfil dos entrevistados 16

$\begin{array}{ll}\text { 4.2. Motivação empreendedora } & 17\end{array}$

4.3. Expectativas em relação ao Empreendedorismo 21

4.4. Dificuldades e Recompensas $\quad 24$

4.5. Pandemia do COVID-19 26

4.6. Dilema empreendedor 29

4.7. Hoje eu estou arrependido por decidir empreender? 30

4.8. O que é o conceito de empreendedorismo na visão dos entrevistados 32

4.9. Ponto de vista sobre a entrevista e a relevância do título abordado no estudo34

4.9.1. Entrevista 34

4.9.2. Título do estudo 36

5. Conclusão 38

5.1. Sugestões e recomendações para futuras pesquisas 40

6. Referências Bibliográficas 42

$\begin{array}{ll}\text { Apêndice } & 44\end{array}$ 


\section{Lista de Tabelas}

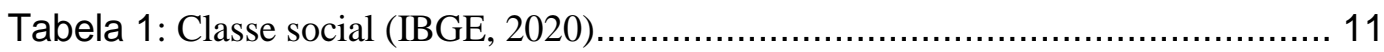

Tabela 2 Perfil dos Entrevistados ........................................................................ 13 


\section{O tema e o problema de estudo}

O objetivo do presente trabalho consistiu em compreender as motivações de jovens brasileiros oriundos de camadas populares a empreender. Neste estudo, entende-se como empreendedorismo toda e qualquer tentativa de criação de um novo empreendimento. Para tal, uma atividade autônoma, que seja formalizada ou não, é considerada uma forma de validação para o objeto de estudo.

\subsection{Introdução}

Há inúmeros estudos sobre empreendedores e seus empreendimentos no geral, porém a literatura acadêmica carece de estudos sobre as especificidades e motivações do jovem empreendedor pertencente às classes sociais menos favorecidas. Portanto, neste trabalho, o objeto central será os jovens que compõem a Geração Y, empreendedores, moradores da cidade do Rio de Janeiro, pertencentes à classe popular brasileira.

No que diz respeito aos jovens da Geração Y, a literatura acerca deste grupo geracional identifica que esses indivíduos possuem uma postura mais exigente, colocando a realização pessoal e a satisfação profissional como principais fatores de motivação no ambiente de trabalho, tendendo a ter atitudes que fomentam a cooperação e a participação, mesmo sendo julgados como individualistas. (SMOLA; SUTTON, 2002; ZEMKE; RAINES; FILIPCZAK, 2000)

Diante das inúmeras características que envolvem estes jovens, é necessário ressaltar que os traços de personalidade influenciam no comportamento e na tomada de decisão, pois existem fatores sociais e culturais que seguem padrões similares (ALSOP, 2008; SMOLA e SUTTON, 2002).

Há inúmeros trabalhos sobre os "Yrs", que apresentam questões sobre os anseios destes jovens tanto da vida profissional quanto do pessoal. Apresentam, também, comparações dos grupos geracionais e os possíveis conflitos que acabam impactando as empresas.

Esse impacto faz com que a empresa procure moldar o seu processo organizacional de forma a entender qual o sentido do trabalho para esses "Yrs". Por meio do estudo de Sá e Lemos (2017), foi possível entender que o sentido do trabalho é definido como um conceito pessoal que cada indivíduo possui sobre os 
conceitos coletivos das experiências vivenciadas no ambiente de trabalho. Tal estudo tem como apoio o artigo de Sá, Lemos e Cavazotte (2014), que relata a heterogeneidade nas respostas de entrevistados que compõem a Geração Y, ou seja, mesmo sendo um grupo com características homogêneas, seguindo os aspectos geracionais, é impossível obter respostas exatamente iguais de todos os participantes.

$\mathrm{O}$ advento da globalização ocasionou um mundo mais conectado, no qual as pessoas possuem acesso à informação muito mais rápido. Além disso, a introdução de ferramentas tecnológicas possibilitou um ambiente de trabalho mais tecnológico e inovador. Essa tendência viabilizou um "casamento perfeito" no que se refere aos anseios dos ingressantes da Geração Y, que visualizaram a oportunidade de trabalhar para si.

Além disso, ao longo dos últimos anos, houve um aumento no número de políticas e programas voltados ao incentivo do empreendedorismo no Brasil, pois entende-se que este impacta diretamente no desenvolvimento econômico do país trazendo inúmeros benefícios, tais como criação de empregos, desenvolvimento do capital intelectual e econômico do indivíduo e contentamento de suas necessidades (EUROPEAN COMMISSION, 2003). Esses fatores citados acima culminaram numa explosão de novos empreendimentos no Brasil a cada ano.

Dados sobre a taxa de novos empreendimentos são divulgados anualmente pela Global Entrepreneurship Monitor (GEM). Após um levantamento realizado dos estudos de 2010 até 2017 da GEM Brasil, é possível identificar um aumento expressivo de empreendedores jovens entre 18 e 34 anos. Em 2010, esses jovens representavam 56,9\% dos empreendedores do Brasil. Já em 2017, esse número representava 65,8\%. De acordo com dados de 2018 revelaram que a Taxa de Empreendedorismo Total (TTE) alcançou 38\%, ou seja, há por volta de 52 milhões de brasileiros que administram seu próprio negócio. Portanto, é possível estimar que em cada cinco brasileiros, dois são empreendedores no Brasil. A expectativa dessa tendência é de aumento no número de novos empreendimentos no Brasil.

Uma variável externa que impactou bastante na elevação dos números de empreendedores foi a pandemia mundial, pois com o aumento do desemprego, muitas famílias mergulharam em uma crise financeira. Houve uma desaceleração do mercado de trabalho e muitos jovens que eram economicamente ativos ou 
pertencentes a essas famílias que foram impactadas negativamente com a perda de renda de um integrante que compunha esse núcleo, enxergaram no empreendedorismo a única solução possível para reverter o atual quadro de instabilidade econômica.

Nesse contexto de pandemia, a tecnologia, mais precisamente as redes sociais vieram como uma ferramenta imprescindível ao passo de revolucionar, de forma positiva, a construção na busca de empreender. Será que essa ferramenta tecnológica veio para ajudar os empreendedores?

É importante ressaltar que o relatório sobre o empreendedorismo no Brasil da Global Entrepreneurship Monitor (GEM) e os dados de pesquisa de campo sobre as expectativas profissionais de jovens das classes menos favorecidas de Silva (2018) revelaram que há, dentre esses jovens, uma motivação empreendedora. Esta constatação levou o autor deste Trabalho de Conclusão de Curso ao interesse em analisar as motivações desses jovens para empreender. No entanto, especificamente, o objetivo é compreender a motivação de jovens brasileiros pertencentes as camadas populares em empreender.

A literatura acerca deste grupo de jovens ainda é carente de estudos mais aprofundados. Os estudos como o de Silva (2016, 2017 e 2018) e Pinto (2017), mostram que existe, entre esses jovens, uma propensão a empreender. Assim, torna-se relevante a análise sobre as motivações que impulsionam os jovens representantes da Geração $\mathrm{Y}$, que compunham às camadas mais populares e empreender.

\subsection{Objetivo Principal}

O presente estudo tem por objetivo entender o que motiva os jovens da Geração Y, pertencentes a classe sociais menos favorecidas a empreender.

\subsection{Objetivos Intermediários}

Para alcançar o objetivo final desse estudo, será necessário realizar um roteiro de entrevistas com o intuito de analisar os objetivos intermediários, tais como: verificar qual o perfil demográfico desses jovens empreendedores; verificar as expectativas iniciais e suas confirmações ao longo da trajetória empreendedora; 
dificuldades e recompensas encontradas ao longo da trajetória dos empreendedores; o impacto da pandemia nos negócios desses jovens; dilemas vivenciados; entender o conceito de empreendedorismo para esses jovens; questionar se o empreendimento desses jovens é a principal renda para eles; entender quais os aspectos positivos e negativos que o jovem vivencia no seu empreendimento e, por último, o ponto de vista sobre a entrevista e o título abordado neste estudo.

\subsection{Delimitação do estudo}

O presente trabalho está delimitado a alguns Jovens pertencentes às camadas populares, que moram na Zona Norte, Zona Oeste e Zona Sul da cidade do Rio de Janeiro e que possuem qualquer tipo de empreendimento seja formal ou informal.

Ressalta-se que o foco do presente estudo está voltado para os jovens empreendedores, independentemente dos tipos de negócios desenvolvidos por esses indivíduos.

\subsection{Justificativa e relevância do estudo}

Em 2015, o autor deste estudo iniciou a primeira experiência com artigos acadêmicos e científicos por meio do PIBIC (Programa Institucional de Bolsas de Iniciação Científica). O tema era "Trabalho e Geração Y" e o título da minha pesquisa era "Trajetórias de Inserção de Jovens das Camadas Populares no Mercado de Trabalho". Em 2016, ele aprofundou o tema com mais entrevistas e resultados. Por último, em 2017, ainda no PIBIC, o pesquisador realizou outra pesquisa científica denominada: "Expectativas Profissionais dos Jovens Brasileiros das Camadas Populares", nesta ele obteve, por meio das análises das entrevistas, resultados expressivos de jovens que possuíam alguma motivação empreendedora.

Sendo assim, ele decidiu dar continuidade a análise em relação às motivações para empreender de jovens oriundos de camadas populares, na qual se sente inserido e representado. 
Portanto, o estudo é de grande relevância para o autor, porque será possível levar todo o seu registro, junto com os estudos anteriores, que são complementares, para as suas futuras pesquisas de pós-graduação. Além disso, será possível entender se a motivação desses jovens empreendedores pertencentes às camadas populares da Geração Y foi por oportunidade ou necessidade. E, por fim, não há como deixar de ressaltar que há na população de empreendedores, uma carência de estudos no que se refere aos jovens empreendedores de baixa renda.

Adicionalmente, pretende-se contribuir através dos resultados do presente estudo no conhecimento sobre as identificações das motivações e razões que levam essa parcela de jovens de classes menos favorecidas a empreender. Portanto, gerando como resultado dados que contribuirão para os próprios empreendedores deste presente estudo e para o Poder Público. 


\section{Referencial Teórico}

Neste capítulo, serão discutidas as características referentes a Geração Y e a caracterização dos anseios profissionais desses jovens. Em relação ao empreendedorismo, discutiremos as características empreendedoras, as prováveis motivações para empreender, tais como por necessidade e/ou oportunidade, porém sem restringir outras possíveis motivações. Por fim, faz-se necessário introduzir temas como empreendedorismo no Brasil e entender as características dos jovens brasileiros de baixa renda.

\subsection{Geração Y}

É notório o grande acervo de estudos a respeito de jovens da Geração Y, grupo de indivíduos com características similares que nasceram entre os anos 1980 e 2000. Tais estudos corroboram para o entendimento desta nova classe que se apresenta como o futuro do mercado de trabalho (VELOSO et al, 2008; VASCONCELOS et al, 2010; VELOSO, 2012; VELOSO et al, 2012).

\subsubsection{Caracterização dos anseios profissionais dos jovens da geração $Y$}

Podemos afirmar que os Jovens da Geração Y possuem uma postura mais exigente, colocando a realização pessoal e a satisfação profissional como principais fatores de motivação no ambiente de trabalho, tendo sempre atitudes que fomentam a cooperação e a participação (SMOLA; SUTTON, 2002; ZEMKE; RAINES; FILIPCZAK, 2000), mesmo sendo julgados como individualistas. Diante das inúmeras características que envolvem estes jovens, é necessário ressaltar que os traços de personalidade influenciam no comportamento e na tomada de decisão, pois existem fatores sociais e culturais que seguem padrões similares (ALSOP, 2008; SMOLA e SUTTON, 2002).

Diante da atual conjuntura global, onde a tecnologia se desenvolve a passos largos e os processos se tornam cada vez mais dinâmicos, os jovens contemporâneos se adaptaram às mudanças e passaram a não reconhecer o trabalho como um ofício fixo, pois a volatilidade e a ambiguidade flexibilizaram este contexto. Outros aspectos que são relevantes para os jovens são o 
imediatismo no crescimento profissional, a ambição e a impaciência, pois entendem que as tarefas que agregam em quesitos como know-how, após serem executadas com perfeição, já não despertam mais interesse. Desta forma, a migração para outras empresas se torna corriqueira (SÁ e LEMOS, 2017).

\subsection{Características empreendedoras}

Este tópico será importante para identificar o que diz a literatura em relação às características que os jovens precisam ter para empreender, comparando com os resultados analisados.

Características tais como inovação, atitude, criatividade, propensão a correr risco, comprometimento, persistência e empatia são, na maioria das vezes, relacionadas às pessoas que desejam abrir seu próprio negócio. Na literatura acadêmica, que aborda o tema sobre as características empreendedoras, há diversos autores que descrevem quais são as principais características para um indivíduo se tornar o dono do seu negócio.

Características como a iniciativa, liderança, a negociação, a visão de futuro, a percepção de oportunidades e conhecimento do ramo devem também ser consideradas (LEZANA, 2004). É perceptível a importância que essas características trazem para quem deseja empreender, porém vale ressaltar que é há muito mais aspectos para começar um negócio e, bem como mantê-lo competitivo e com potencial de crescimento (MINUZZI; GRAPEGGIA, 2004).

\subsection{Motivação empreendedora}

O que leva alguém a ter seu próprio negócio? Em linhas gerais, quando se fala em empreender, é possível perceber que, de forma geral, a motivação maior é ser independente, possuir sua própria autonomia para realizar suas atividades sem estar subordinado a alguém. Além disso, é claro, a ambição de ganhar bastante dinheiro.

Na realidade do dia a dia, deparamo-nos com inúmeros exemplos tais como: a pessoa decidiu sair do seu emprego de carteira assinada para ser empresário; outra, mesmo ganhando muito bem e possuindo inúmeros benefícios trabalhistas em um grande organização, não se sente realizada e aventura-se no mundo do 
empreendedorismo; outro herdar alguma herança de família, seja um dinheiro ou até mesmo um negócio já estabilizado e dar continuidade e; por último, por um motivo fora do seu controle, a perda de sua única fonte de renda/emprego e, por consequência, enxerga o empreendedorismo como uma única solução para resolver seus problemas financeiros.

Neste estudo, o autor delimitou duas motivações (necessidade $\mathrm{x}$ oportunidade), que são pertinentes quando se quer entender o que motiva os jovens de baixa renda a empreender. Além disso, pretende-se entender qual das duas motivações possuem uma maior incidência dentre esses jovens. Porém, como as motivações, de obter seu próprio empreendimento, possuem, em algumas das vezes, motivos que são alheios às suas vontades, qualquer outra citada pelos entrevistados deste trabalho será validada nas análises dos resultados.

\subsubsection{Por necessidade}

Lezana (2004), conceitua que as necessidades podem ter sua origem em função de uma espécie de desequilíbrio interno do ser humano. Ela também afirma que podem vir em forma de um déficit e até um tipo de carência humana. Estado de tensão, desequilíbrio, desconforto e insatisfação são as consequências das necessidades do indivíduo.

Na perspectiva de Benavides Espinosa \& Garcia (2004), um indivíduo pode sentir-se motivado a abrir seu próprio negócio, porque questões socioculturais, tal como a necessidade de ter um emprego, podem impactar diretamente sua condição financeira tanto pessoal quanto familiar. Portanto, como forma de endossá-la, ele enxerga o fato de abrir seu próprio negócio como uma condição urgente. Levando em consideração, é claro, a conjuntura do momento pelo qual ele está inserido, seja a falta de empregabilidade, uma pandemia ou a visão de um futuro perturbador.

A realidade no Brasil mostra que, cada vez mais, empreende-se por necessidade, para fins de subsidiar a falta de renda das famílias brasileiras e a grande dificuldade em conseguir um emprego, sobretudo os indivíduos pertencentes às camadas mais populares (GEM, 2006). Essa realidade se estende até hoje, acentuada ainda mais pela pandemia do COVID-19, propulsora de uma 
divisão de cenário radical de cunho negativo no contexto de empregabilidade, renda e sobrevivência.

Para esse estudo, é importante compreender que para os jovens estudados, empreender por necessidade pode ser entendida como uma motivação gerada pela ausência de renda.

\subsubsection{Por oportunidade}

Nixdorff \& Solomon (2005), diz que reconhecer uma oportunidade é uma habilidade muito importante para se chegar ao sucesso do empreendimento. Quando o indivíduo possui essa habilidade muito forte em si, ele tende a sentir-se motivado ao realizar um novo empreendimento. Assim como, quando o indivíduo identifica uma oportunidade, ele tende a mobilizar seus conhecimentos, habilidades e atitudes para empreender.

Quando o empreendedor identifica uma possível oportunidade de mercado, ele vai em busca de recursos que vão gerar as ferramentas necessárias para a execução da sua ideia. Na visão de Sarason; Dean \& Dillard (p. 8, 2006), “oportunidades são um processo idiossincrático para o indivíduo”. Deste modo, é possível entender que cada empreendedor terá a percepção individual sobre o conceito de oportunidade através de sua visão de mundo, hábitos, costumes e experiências de vida.

Baron (2004), diz que o empreendedor só consegue reconhecer uma oportunidade de negócio por meio do seu mapa cognitivo de conhecimentos. Variáveis tecnológicas, políticas, sociais e econômicas estão inseridas nesse vasto reconhecimento, este por último, demanda o empreendedor possuir conhecimentos anteriores, para que haja uma relação desses dois conceitos: reconhecimento e conhecimento. Ou seja, por exemplo, quando um jovem empreendedor possui conhecimentos de empreendedorismo e/ou administração em uma graduação, facilitarão a percepção de novas formas de inovação empreendedora.

Para esse estudo, é importante compreender que para os jovens estudados, empreender por oportunidade pode ser entendida como uma motivação gerada pela visão de um nicho de mercado potencialmente oportuno. 


\subsection{Empreendedorismo no Brasil}

Diante da conjuntura atual do país, no que tange a pandemia mundial, houve um crescente movimento de empreender, principalmente por brasileiros pertencentes às camadas populares.

Dados da pesquisa GEM de 2019, o Brasil ocupa uma posição que o deixa em evidência entre 55 países que participaram da entrevista.

Segundo o estudo, a $4^{\mathrm{a}}$ maior Taxa de Empreendedorismo Inicial $(\mathrm{TEA}=23,3 \%)$, que representa os empreendimentos existentes até 3,5 anos de existência, é do país. E só para acrescentar mais um dado relevante, essa posição está acima de países representados pelos BRICS, EUA, Alemanha etc.

No que se refere a "Taxa de Empreendedores Estabelecidos", ou seja, o negócio possui mais de 3,5 anos de existência, o país representa a $2^{\mathrm{a}}$ maior marca globalmente. $-(\mathrm{TEE}=16,3 \%)$.

Seguindo esse raciocínio, a Taxa de Total de Empreendedorismo equivalente a $(\mathrm{TTE}=38,7 \%)$, - considerando uma população adulta entre 18 e 64 anos - também deixa o Brasil em destaque na posição de $4^{\mathrm{a}}$ melhor marca mundial e a maior taxa entre os países do BRICS. Além disso, a pesquisa aponta que há no Brasil uma motivação por empreender gerada pela escassez de emprego. Esse dado deixa o país entre os 10 países mundiais que mais empreendem. Outro aspecto importante diz respeito às mulheres, pessoas negras e com idade entre 34 e 55 anos são motivadas a empreender por causa da escassez de emprego. Por último, a motivação de possuir seu próprio negócio representa o $4^{\circ}$ sonho mais citado (37\%).

A pesquisa sugeriu que o avanço da pandemia do ano passado alavancaria o número de empreendedores no país. Essa projeção estaria elencada por fatores tais como a desaceleração da empregabilidade, perda de renda familiar e crescente crise dos fatores econômicos, sociais e políticos.

O presidente do SEBRAE (Serviço Brasileiro de Apoio às Micro e Pequenas Empresas), Carlos Melles argumenta o seguinte:

Com um dos resultados da pandemia do novo coronavírus, acreditamos que neste ano de 2020, o grupo dos empreendedores iniciais cresça e atinja o novo recorde histórico, com uma proporção de $25 \%$ do total da população adulta. Este número, segundo nossa 
projeção, será puxado pelas mulheres, pelas pessoas negras, em geral, os grupos que mais costumam ser afetados pelo crescimento do desemprego.

\subsection{Jovens de Baixa Renda no Brasil}

Diante das necessidades financeiras, muitos jovens buscam por um crescimento profissional e econômico. É notória a busca pela independência financeira e profissional, logo faz-se necessária a inserção, desses jovens oriundos de camadas menos favorecidas, no mundo do empreendedorismo.

Esses jovens possuem trajetórias profissionais distintas, pois a herança social impacta profundamente nas suas vidas. Logo, as experiências vivenciadas por eles influenciam nas perspectivas de seus futuros, fazendo com que os seus interesses sejam moldados de acordo com as suas possibilidades (SILVA, 2018).

É válido ressaltar, finalmente, que por mais que haja inúmeros estudos voltados para o entendimento dos ingressantes da Geração Y, a literatura carece de pesquisas que sejam voltadas a compreender as expectativas referentes ao trabalho de jovens procedentes das camadas populares, principalmente, aqueles que não possuem em seu histórico uma formação superior, ora por falta de oportunidade, ora porque esse anseio não condiz com a sua realidade vivida, na qual a busca pela necessidade financeira ocasionada pelas adversidades em sua trajetória de vida torna-se prioridade. (SILVA, 2018)

A Tabela 2, abaixo, relaciona a classe social de acordo com a renda familiar no ano de 2020.

\begin{tabular}{|c|c|}
\hline Classe social & Renda Familiar (R\$) EM 2020 \\
\hline A & $\mathrm{R} \$ 20.900,01$ ou mais \\
\hline $\mathrm{B}$ & $\mathrm{R} \$ 10.450,01$ a $\mathrm{R} \$ 20.900,00$ \\
\hline $\mathrm{C}$ & $\mathrm{R} \$ 4.180,01$ a $\mathrm{R} \$ 10.450,00$ \\
\hline $\mathrm{D}$ & $\mathrm{R} \$ 2.090,01$ a $\mathrm{R} \$ 4.180,00$ \\
\hline $\mathrm{E}$ & Até $\mathrm{R} \$ 2.090,00$ \\
\hline
\end{tabular}

Tabela 1: Classe social (IBGE, 2020)

A tabela acima servirá como base para identificar e analisar o perfil dos jovens empreendedores da camada popular do Brasil. 


\section{Metodologia}

Este capítulo procura informar como foi estruturada a metodologia adotada neste Trabalho de Conclusão de Curso, possibilitando, é claro, através de um olhar subjetivo do entrevistador, a compreensão dos aspectos relacionados pelos entrevistados.

Em cinco seções, serão apresentadas o tipo de pesquisa adotada; como se deu o processo de seleção dos entrevistados; a realização da coleta dos dados; a decisão da análise dos dados obtidos pelas entrevistas e as possíveis limitações da metodologia utilizada.

\subsection{Tipo de pesquisa}

Após uma análise de dados secundários, observou-se que há poucos estudos sobre o assunto abordado neste presente trabalho. Portanto, a decisão foi de realizar uma pesquisa exploratória, para começar a entender melhor sobre o assunto com o intuito de auxiliar futuras pesquisas no que tange a geração de ideias para testagem de hipóteses para pesquisas futuras.

Além disso, este trabalho pode ser caracterizado como de natureza qualitativa, pois o intuito é conseguir obter os dados dos entrevistados por meio de seus próprios termos e palavras. Este método facilita a empatia, e por consequência propicia o envolvimento do entrevistado durante a entrevista. Além disso, facilita a construção de novas perguntas relacionadas ao que foi dito anteriormente pelo entrevistado com o intuito de obter respostas mais longas e, consequentemente, mais profundas através de suas próprias experiências e conhecimentos sobre o assunto discutido.

\subsection{Seleção dos entrevistados}

A entrevista foi realizada com dez jovens empreendedores, que possuem um empreendimento formal ou informal. Esses empreendedores são pertencentes às camadas populares, nascidos entre o ano de 1980 e o ano de 1995, período relativo à Geração Y. 
Todos os jovens foram selecionados cuidadosamente seguindo os critérios citados acima e, que fizeram ou fazem parte, atualmente, do convívio social do autor deste estudo.

Na tabela 1, a seguir, é apresentado o perfil demográfico dos entrevistados.

\begin{tabular}{|c|c|c|c|c|c|c|c|c|c|c|}
\hline $\begin{array}{l}\text { Entrevistado } \\
\text { (a) }\end{array}$ & Gênero & Idade & Profissão & $\begin{array}{l}\text { Estado } \\
\text { Civil }\end{array}$ & Filhos & $\begin{array}{c}\text { Raça / } \\
\text { cor }^{1}\end{array}$ & Bairro & Formação & Renda Familiar ${ }^{2}$ & $\begin{array}{l}\text { Classe } \\
\text { Social }^{3}\end{array}$ \\
\hline E1 & $\mathrm{F}$ & 36 & $\begin{array}{l}\text { Professora / } \\
\text { Confeiteira }\end{array}$ & Casado & 1 & Branca & Madureira & $\begin{array}{c}\text { Ensino Superior } \\
\text { Completo }\end{array}$ & $\begin{array}{l}\mathrm{R} \$ 4.180,01 \mathrm{a} \\
\mathrm{R} \$ 10.450,00 \\
\end{array}$ & $\mathrm{C}$ \\
\hline E2 & $\mathrm{F}$ & 25 & $\begin{array}{l}\text { Maquiadora } \\
\text { profissional }\end{array}$ & Solteiro & 1 & Parda & Anchieta & $\begin{array}{c}\text { Ensino Médio } \\
\text { Completo }\end{array}$ & $\begin{array}{c}\mathrm{R} \$ 2.090,01 \mathrm{a} \\
\mathrm{R} \$ 4.180,00\end{array}$ & $\mathrm{D}$ \\
\hline E3 & $\mathrm{F}$ & 34 & Administradora & Casado & 2 & Negra & Rocinha & $\begin{array}{c}\text { Ensino Superior } \\
\text { Completo }\end{array}$ & $\begin{array}{c}\mathrm{R} \$ 2.090,01 \mathrm{a} \\
\mathrm{R} \$ 4.180,00 \\
\end{array}$ & $\mathrm{D}$ \\
\hline $\mathrm{E} 4$ & $\mathrm{~F}$ & 27 & $\begin{array}{l}\text { Microempresária } \\
\text { / Do Lar }\end{array}$ & Casado & 3 & Parda & Campo Grande & $\begin{array}{c}\text { Ensino } \\
\text { Fundamental } \\
\text { Completo }\end{array}$ & $\begin{array}{c}\mathrm{R} \$ 2.090,01 \mathrm{a} \\
\mathrm{R} \$ 4.180,00\end{array}$ & $\mathrm{D}$ \\
\hline E5 & $\mathrm{F}$ & 26 & Contadora & Solteiro & 0 & Amarela & Recreio & $\begin{array}{c}\text { Ensino Superior } \\
\text { Completo }\end{array}$ & $\begin{array}{l}\mathrm{R} \$ 4.180,01 \mathrm{a} \\
\mathrm{R} \$ 10.450,00\end{array}$ & $\mathrm{C}$ \\
\hline E6 & $\mathrm{F}$ & 31 & $\begin{array}{c}\text { Empreendedora / } \\
\text { Modelo }\end{array}$ & Solteiro & 0 & Negra & Madureira & $\begin{array}{c}\text { Ensino Médio } \\
\text { Completo }\end{array}$ & $\begin{array}{c}\mathrm{R} \$ 2.090,01 \mathrm{a} \\
\mathrm{R} \$ 4.180,00\end{array}$ & $\mathrm{D}$ \\
\hline E7 & $\mathrm{F}$ & 26 & Autônoma & Solteiro & 0 & Branca & Anchieta & $\begin{array}{l}\text { Ensino Médio } \\
\text { Completo }\end{array}$ & Até $\mathrm{R} \$ 2.090,00$ & $\mathrm{E}$ \\
\hline E8 & M & 34 & Empresário & Solteiro & 0 & Negro & $\begin{array}{l}\text { Recreio / } \\
\text { Itanhangá }\end{array}$ & $\begin{array}{l}\text { Ensino Superior } \\
\text { Incompleto }\end{array}$ & $\begin{array}{l}\mathrm{R} \$ 4.180,01 \mathrm{a} \\
\mathrm{R} \$ 10.450,00\end{array}$ & $\mathrm{C}$ \\
\hline E9 & $\mathrm{F}$ & 37 & $\begin{array}{c}\text { Empresária / } \\
\text { Empreendedora }\end{array}$ & Solteiro & 0 & Preta & Madureira & $\begin{array}{l}\text { Ensino Superior } \\
\text { Incompleto }\end{array}$ & $\begin{array}{c}\mathrm{R} \$ 2.090,01 \mathrm{a} \\
\mathrm{R} \$ 4.180,00\end{array}$ & $\mathrm{D}$ \\
\hline E10 & $\mathrm{F}$ & 29 & $\begin{array}{c}\text { Guarda } \\
\text { Municipal }\end{array}$ & Solteiro & 0 & Negra & Madureira & $\begin{array}{c}\text { Ensino Superior } \\
\text { Incompleto }\end{array}$ & $\begin{array}{l}\mathrm{R} \$ 4.180,01 \mathrm{a} \\
\mathrm{R} \$ 10.450,00\end{array}$ & $\mathrm{C}$ \\
\hline
\end{tabular}

Tabela 2 Perfil dos Entrevistados

Fonte: Elaborada pelo autor, 2021.

${ }^{1}$ A categorização do entrevistado no que tange à raça/cor se deu por autodeclaração.

${ }^{2}$ A renda familiar constitui a soma dos indivíduos que fazem parte do núcleo familiar da casa onde o entrevistado reside.

${ }^{3}$ A classe social é definida pelo IBGE. Leva-se em consideração a renda familiar estipulada pela soma dos salários-mínimos vigentes no ano de 2020. Neste caso, o valor do salário-mínimo era de $\mathrm{R} \$ 1045,00$ reais.

\subsection{Coleta de Dados}

Realizou-se uma pesquisa de dados secundários, os quais possibilitaram a construção do referencial teórico deste trabalho. Nesta pesquisa bibliográfica, buscou-se informações em artigos, livros, internet, periódicos e pesquisas científicas de cunho acadêmico. 
Foram realizadas entrevistas a partir de um roteiro semiestruturado (apêndice), que possibilitou a realização de perguntas abertas direcionando a entrevista conforme os relatos apresentados pelos entrevistados. Todas as entrevistas foram gravadas e integralmente transcritas.

\subsection{Análise dos dados}

Após a coleta dos dados dos entrevistados, o autor transcreveu as gravações em áudio, pois desta forma foi possível identificar com mais precisão as informações chaves dos relatos dos entrevistados, que compuseram a análise dos resultados e a conclusão do presente trabalho. O autor definiu os aspectos importantes que motivaram os "Yrs" deste estudo a empreender. Para isso, usouse frases ou parágrafos para representar os relatos. Por fim, foi usada a técnica de "emparelhamento", que é a associação das análises em relação à literatura acadêmica. Logo, será possível, desta forma, retomar o que foi dito pelos autores e confirmando ou não seus argumentos com as análises das falas dos entrevistados.

\subsection{Limitações do método}

A pesquisa de natureza qualitativa não tem a pretensão de fornecer evidências conclusivas para a determinação de um curso em ação. Ela é conduzida com a expectativa de que será importante a realização de uma nova pesquisa para, enfim, concluir as evidências coletadas nesta com a da anterior.

Como todo e qualquer modelo de pesquisa há suas limitações. No modelo escolhido pelo autor, foi possível identificar os vieses e limitações dos entrevistados e do entrevistador. A disponibilidade de tempo, horário e local foi um obstáculo, pois é sabido, que há na atual conjuntura, uma tentativa de retomada das atividades profissionais, após um ano e meio de pandemia. Alguns entrevistados não quiseram realizar a entrevista via videoconferência, logo o autor teve de adaptar e conduzir a entrevista por meio de aplicativo popular de troca de mensagens em formato de áudio.

Alguns momentos, o local disponível para a realização da coleta de dados não foi o adequado, interferindo na qualidade do áudio e possibilitando uma 
possível distorção do entendimento de uma fala do entrevistador. Outro aspecto foi a limitação da compreensão da pergunta e, consequentemente, da resposta por parte dos jovens empreendedores. E, por último, a não garantia da fidedignidade das respostas por parte dos entrevistados. 


\section{Análise e Discussão dos Resultados}

O presente capítulo está organizado em quatro seções e tem como objetivo apresentar os principais resultados alcançados com a pesquisa, analisando e discutindo suas implicações.

Os resultados gerados por esse estudo foram possíveis através dos dados coletados dos 10 entrevistados. Essas informações vêm à tona trazidas por experiências, vivências e visão de mundo desses jovens. Logo, foi viável compreender o que gerou a motivação desses "Yrs" em empreender; as expectativas iniciais e suas confirmações ao longo da trajetória empreendedora; dificuldades encontradas ao longo da caminho; o impacto da pandemia do COVID-19 e suas implicações; o dilema vivenciado; possível arrependimento em empreender; o que é o conceito de empreendedorismo na visão deles; e o ponto de vista sobre a entrevista e o título abordado neste estudo.

\subsection{Perfil dos entrevistados}

Neste subtópico é apresentado os dados demográficos coletados dos 10 jovens na primeira pergunta da entrevista. Todos entrevistados se enquadram nas camadas populares brasileiras (C, D \& E).

Foi apresentado um quadro contendo as informações sobre a divisão de classes sociais por meio da renda familiar, calculada através do somatório do salário-mínimo vigente ao ano de 2020. O resultado do cálculo e o enquadramento do indivíduo em classe social (A, B, C, D ou E) são de acordo com o IBGE (Instituto Brasileiro de Geografia e Estatísticas).

Segundo o levantamento do GEM, 2019 (Global Entrepreneurship Monitor), há um alto índice de empreendedorismo em relação às mulheres e pessoas negras. Fato este confirmado pelo presente estudo que obteve $70 \%$ da amostra representada por jovens que se declararam negros, pretos ou pardos.

Dos 10 entrevistados, 09 foram mulheres. Portanto, por meio deste estudo acadêmico, é possível inferir que há um número maior de mulheres se aventurando como empreendedoras. A classificação de cor/raça se deu por 
autodeclaração, portanto 2 se consideram brancas, 2 dizem ter cor parda, 3 são negras, enquanto 1 se diz considerar amarela e, por fim, 1 afirma ser preta. O único jovem da pesquisa se autodeclarou negro. Conclui-se que a amostra é constituída por pessoas negras (40\%), pardas (20\%), amarela (10\%), branca (20\%) e preta $(10 \%)$.

A idade dos jovens variou entre 25 e 37 anos e a média de idade ficou na casa dos 30,5 anos. O estado civil "Solteiro" representou (60\%), contra os (30\%) "Casado" e (10\%) "Divorciado". Desse universo de solteiros, apenas 1 possui filhos. Entre os dois jovens casados, um teve três filhos e outro, dois filhos. Os demais não possuem ou não têm a intenção, por enquanto, de ter um. Os bairros onde esses jovens moram estão localizados entre as zonas norte, sul e oeste da cidade do Rio de Janeiro.

Já em relação à formação acadêmica, o Ensino Superior Completo, Ensino Superior Incompleto e Ensino Médio Completo apareceram empatados com (30\%) respectivamente, enquanto um apresentou Ensino Fundamental Completo (10\%). Por fim, ao analisar a renda familiar informada por cada um, foi possível identificar que dentre eles, a classe " $D$ " é predominante, pois ela é representada por $(50 \%)$ da amostra, enquanto a classe "C" obteve $(40 \%)$ e a classe "E" apareceu timidamente com os seus (10\%).

\subsection{Motivação empreendedora}

O conceito de motivação, normalmente, está diretamente ligado aos sentimentos que vêm do coração. Neste presente estudo, o autor não poderia deixar de lado a sensibilidade ao abordar esse tema, porque o objeto de estudo, que são esses “jovens estrelas” (visão do autor), na maior parte de sua trajetória de vida, carregam bagagens de vida consideradas pela sociedade muito "pesadas" causadas pelas inúmeras dificuldades tanto financeiras, profissionais ou falta de oportunidade.

Não é fácil se colocar no lugar deles, pois muitos no dia a dia estão à margem da sociedade tentando sobreviver acreditando que o empreendedorismo seja a última alternativa de renda. Com os depoimentos foi possível perceber que mesmo não tendo oportunidade de acesso ao conhecimento, eles assumem riscos 
(muitas das vezes, sem consciência) e incorporam para si a famosa característica empreendedora denominada "atitude".

O autor desse estudo - à princípio - delimitou a pesquisa entre dois conceitos relacionados à motivação empreendedora: oportunidade x necessidade. Porém, ao decorrer da pesquisa, especificamente, no trabalho de campo, ele percebeu que a motivação é causada por motivos, às vezes, alheios ao empreendedor.

$\mathrm{Na}$ literatura acadêmica, os autores que estudam a Geração Y dizem que ela possui a homogeneidade nas atitudes e no pensar, porém quando se vai a campo indagar essa afirmação, a heterogeneidade das respostas leva a questionar a que ponto a literatura deve generalizar os millenials, pois a vivência desses "Yrs", do presente estudo, faz-se distinta das experiências dos "Yrs", que são das camadas sociais superiores.

Silva (2018), afirma que a busca pela necessidade financeira, ocasionada pelas adversidades em sua trajetória de vida, torna-se esta motivação como prioridade na vida do jovem empreendedor. Como era de se esperar, a necessidade em empreender obteve um índice muito maior do que a motivação por enxergar alguma oportunidade em um nicho de mercado.

A necessidade foi gritante na minha vida, porque foi do
empreendedorismo que tirei o sustento do meu filho. (E2)

Gerar recursos para não só elevar minha empresa dos sonhos, como alcançar meus objetivos pessoais. (E4)

A necessidade, com certeza, porque a minha família nunca teve estrutura assim financeira. meu pai motorista, minha mãe empregada doméstica. (E8)

No meu caso foi a necessidade financeira. (E10)

$\mathrm{Na}$ época, quando a gente abriu a loja foi por necessidade e pra ajudar na renda extra na própria casa, porque a gente só dependia do trabalho do meu pai, que era mecânico. Minha mãe estava com o meu irmão pequeno de um ano. Então, ela não poderia sair para fazer as vendas dela. (E7) 
Durante a entrevista, após uma breve reflexão, alguns jovens chegaram à conclusão de que a motivação foi gerada pelo mix de necessidade/oportunidade, embora a necessidade tenha sido a motivação prioritária no início de decidir empreender.

Ganhar dinheiro, porque eu fiquei desempregada e como eu já sabia fazer bolos e as pessoas falavam muito bem de mim, eu aproveitei a oportunidade e decidi começar o empreendimento. (E1)

A necessidade de aumentar minha renda e vi uma oportunidade que foi meu pontapé de realizar um sonho com lucros, com renda e qualidade de vida. (E3)

Outros aspectos motivadores levantados pelos jovens que possuem filhos, são justamente enxergar o empreendedorismo como uma forma de solução para um futuro melhor para as crianças.

Veio o empreendedorismo. Comecei a investir em mim e no meu sonho, mas o grande motivador disso tudo até hoje é o meu filho. (E2)

Comecei por causa dos meus filhos. (E4)

Um ponto levantado na entrevista foi entender se o jovem teve alguém que o tivesse influenciado a trilhar no mundo do empreendedorismo.

A influência que eu tenho é o meu filho, mas eu não possuo ninguém de base. (E2)

O meu pai foi um empresário. Ele foi um grande motivador, porque foi através dele que eu tive contato com vendas e atendimento ao cliente. (E9)

Meu padrinho que era um empreendedor me influenciou. (E8)

Meu marido. (E1) 
Eu tenho uma influência forte da minha mãe. Ela sempre vendeu as coisas dela. Trabalhou no ramo de cama mesa e banho e até vendeu cachorro-quente na barraquinha. (E3)

Em relação à oportunidade, foi destacada a falta de políticas públicas para os jovens de comunidades, como forma de "abrir os olhos" enxergando o empreendedorismo com forma de mudar de vida.

$\mathrm{Na}$ comunidade onde eu morava falta oportunidade, porque eu acredito que se tivesse mais sistema comunitário, poderia levar o empreendedorismo para qualquer pessoa, como por exemplo, cursos gratuitos. (E2)

O fato de trabalhar como CLT (Consolidação das Leis do Trabalho) e para outras pessoas provoca um incômodo em alguns entrevistados. Nixdorff \& Solomon (2005) dizem quando uma oportunidade é reconhecida por um indivíduo, ele mobiliza o conhecimento, atitude, habilidades presentes dentro de si como fator motivacional para empreender. Este aspecto pode ser confirmado por meios das respostas de alguns entrevistados abaixo:

Eu não aguentava mais minha patroa me mandando e não me pagando direito. Promoveu-me como gerente, mas o salário não era compatível. (...) Eu tenho que sair dessa vida de trabalhar para os outros e ficar sendo humilhada. Eu gostava de ficar fazendo cabelo, então eu decidi empreender. (E6)

Sair do CLT, vislumbrar um salário maior e ter liberdade de horário. (E9)

Me incomodava trabalhar para alguém, como receber ordens. Às vezes, eu queria executar algo do meu jeito ao meu entender era o melhor, mas nos olhos do meu gerente não era. Eu não tinha autonomia, e não colocar as minhas ideias na mesa era como seu estivesse preso numa gaiola. (E8) 
Um aspecto importante foi perceber que em relação aos empreendedores que já estão há bastante tempo no mercado e com seus empreendimentos estáveis, a motivação empreendedora mudou para o aspecto social.

\footnotetext{
Hoje, depois de algumas transformações em minha vida, após algumas passagens de crescimento pessoal, a minha visão de empresária mudou completamente. Então, agora é o impacto social que a minha empresa pode causar na vida das pessoas ou na economia do país. (E9)
}

Hoje, a minha empresa possui uma pegada muito forte no social. Fazemos vários projetos sociais nas comunidades onde a gente atua. (E8)

Outro aspecto importante citado por alguns jovens é o fato da realização pessoal como um aspecto forte na decisão de abrir seu próprio negócio. Os jovens da Geração Y tendem a possuir uma postura mais exigente ao escolher um ambiente de trabalho que os satisfaça como profissionais e, é claro, a realização pessoal como aspectos motivacionais. (SMOLA; SUTTON, 2002; ZEMKE; RAINES; FILIPCZAK, 2000). Além disso, uma entrevistada citou a realização pessoal da mãe como um forte motivador para ela.

\footnotetext{
O que me motiva empreender é realizar o sonho de ter o meu negócio. Mas, eu quero um negócio de coisas feitas por mim, porque desde criança eu amei a área da costura, do artesanato, da criação. (E3)

A minha maior motivação era o sonho da minha mãe. O fato dela gostar muito de trabalhar na cozinha fazendo comida. (E5)
}

\subsection{Expectativas em relação ao Empreendedorismo}

Neste tópico, o objetivo foi compreender as expectativas dos jovens em relação ao empreendedorismo no Brasil antes de decidir empreender e, em quais medidas elas foram confirmadas após a trajetória empreendedora. 
Eu tinha receio, porque a gente sabe que no Brasil tudo é taxado e a burocracia é muito grande. (E1)

Eu tinha uma visão.... a gente que vem de camadas populares, não temos muito acesso a algumas coisas. A gente vê pela forma subjetiva. Eu achava que empreender era pra quem tinha dinheiro. (E10)

Eu achava que empreender, eu ia ganhar rios de dinheiro, eu não ia precisar cumprir horário, ter chefe, mas quando a gente começa empreender, a gente vê que é totalmente diferente. (E3)

O autor deste estudo, após ouvir atentamente as respostas desses jovens estrelas, percebeu que os que possuem já uma experiência no empreendedorismo indaga que aspectos externos, como as variáveis políticas (Governo) e econômicas (carga tributária e crise econômica) impactam consideravelmente o negócio. Acredito que isso se dá pelo fato das experiências do dia a dia e porque o empreendimento já possui uma estabilidade no mercado. Entretanto, os empreendedores que possuem um negócio considerado pequeno e ainda em desenvolvimento inicial, não destacaram esses pontos nas entrevistas.

O custo dos meus produtos é alto. Eu preciso de investimento, mas o Brasil não ajuda. Eu acredito que lá fora (Exterior), a minha arte tenha uma visão muito diferente daqui. (...) a crise econômica e a pandemia fizeram com que os preços subissem muito, logo a dificuldade em investir. (E2)

Hoje em dia, a tecnologia está bastante avançada e nos ajuda bastante, mas em questão ao Brasil, talvez, baixar os impostos, as taxas de luz etc. (E4)

O ponto mais negativo de todos é a falta de apoio econômico, de incentivo para o empreendedorismo por conta do Governo, pois ele é extremamente solitário, hostil por conta da taxação de juros. O quanto você perde honestamente, corretamente, o quanto você é impedido eu já fui embargada por causa de vistoria de vigilância sanitária. (E9) 
Empreender no Brasil é muito difícil, porque você esbarra em muitas regras sem sentido e burocracias. Você esbarra com a necessidade de ter relacionamento com o Poder Público. A impressão que tem é que a gente está pedindo um favor. (...) Eu durmo menos. A ingratidão de funcionários. Os funcionários têm mais direitos que a gente. Demitir alguém também é muito chato. (E8)

Uma curiosidade que chamou a atenção do autor do presente estudo foi o fato de que alguns ao tomarem a decisão de empreender não esperavam nenhuma expectativa, portanto esta informação corrobora com a pesquisa do GEM, quando os resultados mostraram que o empreendedor por necessidade possui essa característica. Não calcularam os riscos e nem realizaram um planejamento inicial. Apenas, foram e fizeram. Talvez, a necessidade de renda pessoal ou do núcleo familiar, como um único pedido de socorro, viabilizou todos os riscos técnicos de um empreendimento. Além da desigualdade social que é um abismo e a dificuldade ao acesso às informações, que promovem o conhecimento técnico confirmam o porquê de os entrevistados não terem tido alguma expectativa em relação ao empreendedorismo.

Portanto, os que não consideravam alguma expectativa tanto no que o negócio poderia trazer como retorno financeiro, alguma realização pessoal, ou quais variáveis externas ou internas poderiam impactar positivamente ou negativamente, resultaram na anulação da pergunta que busca entender de que forma as expectativas iniciais foram confirmadas ao longo da trajetória empreendedora.

Na verdade, eu nunca tive uma visão sobre isso, porque você começa ter a visão e pesquisar a fundo, quando você já está ali. então, eu confesso que antes de empreender, eu não tinha a visão do que era antes no Brasil. E eu acredito que muitas pessoas ainda não tenham essa visão, assim como eu. (E2)

Não sabia o que esperar na verdade. Fui à força e à coragem. (E4)

Eu não esperava nada, pois eu não tinha noção do que era empreender, do que era o impacto em empreender. Eu não tinha noção do que era a economia, contábeis, custos. (E9) 


\subsection{Dificuldades e Recompensas}

Todos nós passamos por inúmeras dificuldades ao longo da nossa vida e no campo profissional. Não seria diferente esperar o contrário nas respostas dos entrevistados. É sabido que a condição financeira e social desses jovens impacta diretamente na vida e, principalmente, na tomada de decisão no que diz respeito a ser um empreendedor. Foram inúmeras dificuldades enfrentadas por eles ao longo da trajetória empreendedora.

O custo operacional alto foi bastante citado na entrevista:

O início é muito difícil. Eu comecei a ver lucros com três anos de empresa. Não é porque você faz bem, que vai fazer sempre. (E1)

O custo operacional era muito alto e a gente teve que repassar para os clientes. Desse jeito foi desmotivando a continuar. Além disso, é conciliar o empreendedorismo com o CLT. (E5)

Logo no começo, no primeiro ano, eu fechei no vermelho. Eu percebi que o custo operacional era altíssimo. O desespero bateu. Eu fechei a empresa, dei um passo atrás pra seguir. Além disso, escassez de mão de obra qualificada no mercado (E9)

Investimento e retorno como dificuldades ao longo da trajetória empreendedora:

Quanto mais você investe, mais retorno você tem. Só que para investir, pra empreender, precisa ter fundos, mas quando você não tem fundos suficientes, torna - se mais difícil. (...) Além disso, eu sofri um atentado dentro do trem. Eu quase perdi minhas ferramentas para realizar meu sonho como empreendedora. (E2)

Trabalhar em conjunto no meu primeiro empreendimento foi horrível! Os sócios estavam juntando o dinheiro do bar com o dinheiro pessoal. Eu estava investindo dinheiro, mas não estava vendo retorno, somente prejuízo. (E10) 
Quando houve a queda das vendas das máscaras. Além disso, eu tive uma dificuldade técnica, porque eu fiquei sem máscara para fazer. (E3)

Porém, é necessário citar também os aspectos positivos da trajetória empreendedora dessas estrelas. Neste estudo, eles serão representados pelo conceito de recompensas.

Conhecimento e desenvolvimento foram pontos de partida:

Conhecimento é o grande aspecto positivo, porque é o mundo. Além de levar autoestima para as minhas clientes e ensiná-las como se maquiar. O resultado e o feedback são muito importantes. (E2)

O meu crescimento pessoal foi absurdo. O empreendedorismo quebrou o meu paradigma de limitação, que a sociedade impõe de “quem nasce pobre, vai morrer pobre". Eu lido com pessoas altamente influentes. O presidente da república é o meu cliente. Mesmo eu tendo uma renda muito baixa, eu atendo as pessoas da elite do Rio de Janeiro. Eu entro e saio de rodas sociais altíssimas da mesma forma que eu entro e saio da academia em Madureira. Se não fosse pelo empreendedorismo, isso não seria possível. (...) Eu ganhei o concurso da FGV como Empreendedora do Ano de 2020. (E9)

É muito gostoso empreender. É ver as pessoas que trabalham comigo se desenvolvendo; dividir os meus conhecimentos com os funcionários; ver o sonho da empresa se materializando. Ver valor monetizado e os valores da empresa. (E8)

Ver o quanto você está agregando, ajudando as pessoas. O feedback positivo dos clientes. A gratificação de ver o retorno positivos dos clientes. (E5)

Fazer o que gosta, o que ama, além de não possuírem a visão das atividades desempenhadas como uma forma de trabalho foram aspectos levantados por esses jovens empreendedores:

Eu me sinto em casa. Não sinto aquela pressão que eu sentia quando trabalhava para os outros. Bebo minha cerveja e ofereço até para os 
meus clientes e vira uma festa. Eu vendo e ganho dinheiro. Gosto mais de estar na loja do que em casa. Tenho motivo para acordar cedo. (E6)

Eu trabalho com o que eu amo, então eu não me sinto trabalhando. A gente acaba se tornando amigo dos clientes. (E1)

$\mathrm{Eu}$ tive coragem para fazer o que eu gosto de trabalhar nessa área artesanal. Eu fico feliz de estar no meu ateliê o dia inteiro, porque eu amo fazer. Reconhecimento das pessoas e elogiam as minhas peças. (E3)

\subsection{Pandemia do COVID-19}

A pandemia veio para desestruturar o mundo em todos os seus aspectos sociais, políticos, econômicos, culturais e demográficos. O mundo VUCA (Volátil, incerto, complexo e ambíguo) tanto falado e discutido no mundo acadêmico e corporativo, faz-se presente na prática, atualmente, na vida de qualquer indivíduo. A pandemia mudou os hábitos e costumes das pessoas. De repente, o uso de máscara e álcool gel tornaram-se obrigatórios no combate ao vírus e a sobrevivência do ser humano.

O coronavírus deixou o presente e o futuro ainda mais incertos, as dúvidas e incertezas de uma nova doença, ora com uma taxa de mortalidade alta, ora baixa; grave, não tão grave. Governos sendo negligentes, enquanto outros assumindo os seus papéis com suas devidas responsabilidades de ajudar o seu povo financeiramente por meio de políticas públicas como o auxílio emergencial e incentivando todos a abraçarem a causa no combate à pandemia. Famílias sendo desestruturadas financeiramente. Brasileiros perdendo seus empregos e suas dignidades causando a volatilidade das classes sociais brasileiras.

E agora? O que eu faço da vida? Será que empreender é a minha última solução? Eu que já sou um empreendedor, qual foi o impacto (positivo ou negativo) da pandemia no meu negócio? Após um ano e meio do início da pandemia, quais as principais mudanças que eu percebi no meu negócio?

Outro dado relevante foi o resultado no que diz respeito ao impacto da pandemia no negócio que ficou bem dividido, pois depende do ramo do empreendimento escolhido pelo jovem. As respostas foram sempre padrão: 
positivo ou negativo/nenhum impacto. Houve um caso de uma entrevistada que, logo após o início da pandemia, ela percebeu rapidamente uma oportunidade em outra área e acabou obtendo um retorno positivo.

Eu não tive muito impacto negativo, porque eu fui pra outra área, como eu sou professora e todo mundo estava em casa, eu comecei a dar aula, para ensinar as mulheres a maquiar. Então, eu perdi numa parte e consegui em outra. (E2)

Outro relato foi de a entrevistada afirmar que vendia máscaras no período da pandemia, mas ao decorrer que todos já possuíam os seus produtos, ela teve que criar outra oportunidade diversificando o seu portfólio. Ela relata que a máscara, impulsionada pela pandemia, foi só start para ela começar de vez o seu sonho como empreendedora.

Eu comecei a investir em novos produtos. Foi aí que eu realmente entrei no que eu queria fazer que são bolsas e organizadores. A máscara foi só um pontapé inicial. (E3)

Após um ano e meio do início da pandemia, muitos entrevistados perceberam muito mais mudanças positivas que negativas em seus negócios. Por meio dos relatos foi possível identificar que o conselho dito por eles foi para não desistir. Esse padrão nas falas pode ser entendido como um reforço que ajuda a internalizar em si o próprio conselho.

Eu consegui meu salão. Consegui abrir uma área muito legal dentro do meu empreendimento (E2)

$\mathrm{Eu}$ acrescentei mais produtos na minha loja, que eu nem pensava em trabalhar. Contratei mais funcionários e até fiz uma sociedade. (E6)

A minha empresa criou uma empresa online e hoje ela é uma marca reconhecida na internet. (E9)

Cuidado com a proteção da saúde e dos meus funcionários. Houve um impulsionamento das minhas vendas. (E8) 
A queda na clientela e aumento dos preços dos insumos. (E1)

Ele cresceu de uma forma positiva. Nós conseguimos fidelizar uma clientela. (E10)

A queda das vendas. Aí eu tive que me enquadrar num produto que mais é comum na população. (E3)

$\mathrm{O}$ aumento das vendas fez eu ir mais vezes comprar mercadorias para a loja. (E7)

Um ponto importante relatado pelos entrevistados é o fato da tecnologia se fazer importante e essencial, principalmente, na pandemia. Uma ferramenta dita por eles é a rede social Instagram como forma de divulgar e vender seus produtos. Este fato corrobora com o que Silva, (2018) reforça em seu estudo ao afirmar que as ferramentas tecnológicas possibilitaram os jovens da Geração Y a visualizarem uma oportunidade de trabalhar para si mesmo.

\footnotetext{
Eu não entraria nas redes sociais agora, para venda online. Provavelmente daqui a alguns anos será necessário, mas elas aceleraram as vendas. (E9)
}

Eu entro ajudando na parte da tecnologia (Instagram e aplicativos de entrega) e a minha mãe na mão de obra. (E10)

Eu faço minhas vendas no Instagram. (E3)

Hoje em dia, é inevitável ter uma loja e não ter um Instagram, uma rede social para aquela loja. Todo mundo procura na rede social se lá tem boas referências, se o visual é atrativo. A internet é um ponto principal para captação de cliente. (E5)

É importante ressaltar que estar atento às variáveis internas e externas são de suma importância. Para administradores e empreendedores a regra é a mesma. Mas, será que os jovens deste trabalho possuem essa consciência? Como forma de investigar esse ponto, foi realizada a seguinte pergunta: "Você acompanha as notícias pelo mundo?" Uma minoria disse que sim, mas grande parte não possui 
esse hábito, ou pelo menos tenta, uma vez que o argumento foi que o tempo é um aspecto que impacta negativamente esses empreendedores.

Sou ligada, mas nem tanto. (E2)

Sempre quando dá, sim. (E4)

Sim, sou. Eu me interesso com o trabalho, como o mercado está reagindo e a política. Olho o mercado financeiro, porque eu opero nele. (E8)

Particularmente, não. (E10)

Sim, acompanho. Não sou de ficar assim ligada o tempo inteiro, mas sempre estou vendo as notícias pelo celular ou telejornal. (E3)

\subsection{Dilema empreendedor}

É importante buscar essa resposta através dos entrevistados, por que será que o dilema é relacionado, na maioria das vezes, por questões financeiras dentre os jovens empreendedores das camadas populares? Talvez ele seja identificado por meio da vivência do dia a dia no empreendimento? A pergunta idealizada para os entrevistados foi a seguinte: "se você pudesse falar, qual seria o maior dilema vivenciado desde quando decidiu empreender"? Parece ser uma pergunta bem simples de responder, entretanto foi uma das indagações que promoveu uma maior reflexão dos jovens estudados nesse estudo.

Renda versus Sobrevivência:

Gerar renda, dividir essa renda com várias famílias, mas pagar tanto de tributo. O que eu tenho dá para eu viver? Eu preciso mesmo estra aqui empreendendo e pagando isso tudo de imposto? (E8)

Conciliar empreendedorismo com outros aspectos:

Conciliar o trabalho, comprar mercadorias para o empreendimento, faculdade, casa. (E10) 
Reinventar

Se reinventar. A capacidade de encontrar na dificuldade uma solução e poder adaptar sem perder os valores. (E9)

Não desistir

Não desistir, porque não vai ser fácil. As pessoas vão se levantar contra você. (E2)

Pandemia

Logo após a flexibilização da pandemia, eu pensei em fechar minha loja, mas aí o dono conversou comigo e permitiu que eu pagasse as dívidas em atraso. Eu abri a loja e consegui no mesmo dia o dinheiro pra quitá-la. Eu acho que o auxílio emergencial ajudou. (E6)

Qualidade versus quantidade:

Até que ponto vale ganhar pela quantidade do que pela qualidade? Até que ponto vale comprometer o meu nome, nome da empresa por causa da quantidade? (E1)

\subsection{Hoje eu estou arrependido por decidir empreender?}

Neste tópico, foi possível identificar se a motivação que esses jovens tiveram lá no início da trajetória empreendedora foi válida, pois os aspectos mencionados confirmam, de um certo modo, o sucesso ou o fracasso da tomada de decisão.

Por incrível que pareça, até o exato momento da entrevista, todas as respostas foram unânimes. Nenhum jovem desse estudo, pertencente a Geração Y e classificado nas camadas populares da cidade do Rio de Janeiro, apresentou arrependimento por empreender. Isso mostra que, mesmo diante das dificuldades vivenciadas por ele, a persistência e o fato de não desistir dos seus sonhos e objetivos de vida fazem ele correr o risco do empreendimento, mesmo não tendo pelo menos o mínimo de conhecimento técnico para empreender.

Lezana (2004), reforça que iniciativa, fazer o que gosta, empatia, persistência visão de futuro e percepção de futuro além do know-how sobre o ramo de negócio, são características importantes de quem é empreendedor, que são reforçadas pelos relatos dos entrevistados deste estudo. 
Todo dia eu acordo com vontade de empreender mais, mas você precisa investir. (E2)

Não me arrependo, porque é o que eu amo fazer. Eu não sabia que eu amava tanto assim. (E6)

Não. Na verdade, se hoje eu pudesse escolher em trabalhar para alguém ou continuar investindo, eu continuaria sendo empreendedora, pois é algo gratificante no que podemos fazer. (E4)

Nunca, porque ela é a minha pedra da salvação. Ele quem mudou a minha realidade e de todas as pessoas do meu ecossistema. De trabalho e de família. (E9)

Não, nem um pouco. Amo que eu faço! (E8)

Não, porque ele não é minha única renda. Se eu tivesse que viver da empresa, eu já teria desistido. (E1)

Não, de forma alguma. O empreendedorismo te dar uma liberdade financeira e não ter de dar satisfação para ninguém. (E10)

Não, nem um pouco. Eu amo isso aqui. (E3)

Não, não me arrependo porque me traz retorno financeiro e a gratificação de ajudar as outras pessoas? (E5)

Não, não me arrependo, não, porque foi o que levantou a família e ajudou muito financeiramente. (E7)

Neste tópico, é relevante entender qual a reflexão que esses jovens possuem de si mesmos. Para tal, foi questionada qual seria o diferencial perante os seus concorrentes. Os resultados mostraram que alguns incorporam aspectos relacionados com a subjetividade. Há uma provável ligação com a realização pessoal de cada um.

Eu quero ser reconhecida, porque eu sou a melhor e não porque eu sou a mais barata. (E2) 
Trabalhar com amor. (E6)

Ter sensibilidade e empatia; ouvir o outro; ser comprometido com os meus ideais. Ética e credibilidade. (E8)

Além de fazer as coisas com carinho, com todo cuidado, com amor e perfeição. Os produtos são artesanais. São feitos manualmente selecionados por mim. Além de ter a possibilidade de ter um produto exclusivo. (E3)

A minha dedicação e como eu me dedico a fazer tudo certo. Eu tento ajudar de todas as formas possíveis. (E5)

Já outros, incorporam a missão do negócio:

Serviço de qualidade. Produtos de qualidade com garantia de atendimento excelente. (E4)

Fazer para o meu cliente algo de qualidade que eu gostaria de receber. (E1)

Agilidade, preço, qualidade, rapidez, tempo, disponibilidade (E10)

Era o sabor da comida e porque era feito com alimento totalmente saudável. O que era light, era. O sabor era diferencial. (E5)

Temos de tudo que pode buscar rápido. Quando uma pessoa precisa vem correndo aqui para uma emergência. Aqui é tipo um lugar de emergência. (E7)

\subsection{O que é o conceito de empreendedorismo na visão dos entrevistados}

O autor do presente estudo decidiu fazer uma provocação para entender a visão do que é o conceito de empreendedorismo para esses jovens estrelas. O objetivo foi compreender qual a visão e o entendimento desse conceito para eles. Ressaltou-se que não havia respostas certas ou erradas, pois, a intenção era de identificar na resposta de cada entrevistado, o que o conceito traria de bagagem de 
mundo e sua visão, além das experiências de vida. O objetivo do autor ao criar a provocação desses jovens entrevistados é para averiguar o que Sá e Lemos (2017), reforça ao dizer que o sentido do trabalho para os millenials é definido como um conceito pessoal que cada um possui através das suas experiências vivenciadas no ambiente de trabalho.

Observou-se que não foi uma resposta fácil de responder, pois os jovens pararam para refletir, ainda mais, porque foi solicitada que a conclusão teria de ser em apenas uma frase. Foi possível perceber que os relatos foram distintos e isso é reforçado por Sarason; Dean \& Dillard (p.8, 2006) ao afirmarem que por causa dos hábitos, costumes e experiências de vida, o conceito de empreendedorismo terá uma visão diferente percebida por cada indivíduo.

Não desistir é um aspecto muito importante do empreendedorismo.

Continua que vai te dar o retorno. Não vai ser de imediato. Persevere. Não desista! (E2)

Liberdade é um ponto que chama bastante a atenção do jovem empreendedor, principalmente, quando diz respeito trabalhar para si mesmo.

Uma liberdade, porque eu fiquei presa muitos anos. (E6)

Atitude é algo indispensável para dar ação ao que se deseja fazer.

Pra mim, é você ter uma ideia e fazer acontecer. (E4)

Investimento pode ser uma dificuldade para os entrevistados, porém foi possível perceber que uma grande parcela dos entrevistados cita esse aspecto ao relacionar o conceito de empreendedorismo.

Empreender é você investir em algo que você tenha lucro. (E1)

Transformação para si e para as pessoas envolvidas nos sonhos desses jovens empreendedores.

Pra mim, empreender é viver do que ama. É construir algo que vai transformar a vida de alguém através daquilo que você gosta. (E3)

É poder levar o que há de melhor em você para o mundo conhecer. 
O empreendimento é o reflexo daquilo que você é como pessoa. (E9)

Saber gerar dinheiro através de novas ideias ou ideias que seriam ultrapassadas, mas que as pessoas não estão sabendo explorar ainda. (E10)

Futuro de uma condição de vida melhor. Oportunidades melhores.

Possibilidade de novos caminhos. (E7)

\subsection{Ponto de vista sobre a entrevista e a relevância do título abordado no estudo}

O objetivo, neste tópico, é trazer à tona o feedback dos "Yrs" estudados neste estudo, como parte importante dos achados que a presente pesquisa trará para mim - como autor - quanto para a sociedade refletir e se conscientizar que não é o recomendável generalizar os jovens da Geração Y e os indivíduos que se motivam em abrir um empreendimento. Acredita-se que o presente estudo formará uma reflexão e conscientização sobre o que motiva um jovem de baixa renda, caracterizado como um "Y" a ser um empreendedor.

Um ponto importante destacado na análise do autor deste estudo, foi saber que essa pergunta promoveu também uma reflexão nesses jovens. Acredita-se que muitos deles, após as entrevistas, tomaram ciência que de fato são empreendedores, pois não importa se o seu negócio é informal ou formal, de pequeno porte, médio ou grande. Eles oferecem um produto ou serviço que contribuem para a melhora da vida em sociedade.

\subsubsection{Entrevista}

A entrevista foi maravilhosa! Perfeita! Não tenho palavras e fico imensamente grata por estar participando nesse momento. Eu jamais pensei que estaria aqui numa entrevista de faculdade falando um pouquinho do pouco, do mínimo do que eu já empreendi. (E2)

$\mathrm{Eu}$ amei a entrevista, porque eu nunca havia me feito essas perguntas, nunca havia pensado. Eu respondendo aqui, eu estou vendo o quanto eu evoluí no meu trabalho. Então, faz muito bem para o empreendedor para ele ver o quanto faz diferença na vida dele. Que eu mesma estou 
trabalhando igual máquina, não sentei pra pensar se está dando certo. (E6)

Me achei importante. Achei as perguntas bem elaboradas. É legal conhecer e como cada um entende sobre o seu negócio e acredito que assim, possa ajudar futuramente muitos a pensarem sobre o assunto. (E4)

Eu nunca havia sido entrevistado. Humildemente, eu acho que eu não merecia ser entrevistado, porque eu ainda tenho uma longa estrada para percorrer ainda. Uma entrevista dessa de alto nível. Eu considero você um cara muito inteligente pelas vezes que a gente conversou. Sempre conversei isso com as pessoas mais próximas. Quero agradecer você ter vindo aqui. É a primeira experiência de falar um pouco sobre a minha vida e da minha empresa. (E8)

As perguntas foram pertinentes ao tema. Achei muito coerente dentro do que você está propondo estudar. (E1)

$\mathrm{Eu}$ gostei muito. Achei as perguntas muito pertinentes. Me fez repensar... porque a gente vai vivendo a situação no dia a dia e a gente nem para pra pensar, e aí as perguntas me fizeram refletir o quanto eu e minha já conquistaram desde o início. Você perguntando o que você teve de retorno... são coisas que eu nunca tinha parado pra pensar. Aí eu achei interessante, porque você respondendo ai você pensa: "poxa, teve isso, teve aquilo." faz você ter um balanço geral. As questões negativas, aí você" nossa, faz sentido". (E10)

Eu achei maravilhosa! Adorei as perguntas super bem elaboradas. Está de parabéns, André, como sempre! Eu gostei bastante, porque você fez eu refletir sobre alguns aspectos do meu negócio que nunca havia reparado pra anotar, pra entender, pra botar um planejamento bonitinho. Eu vou usar até de base as minhas respostas para fazer uma lista do que eu quero. Eu adorei! As perguntas foram muito bem elaboradas e eu consegui desenvolver coisas que eu achava que eu não ia conseguir nem responder bem e conceitos do meu negócio que eu não havia nem definido, eu consigo definir agora com a sua entrevista, com as suas perguntas. Então foi maravilhoso, me ajudou pra caramba e adorei! (E3) 
Eu amei a entrevista e o assunto abordado. Tudo que você faz, faz bem-feito. Eu sou sua fã. Não sei se isso pode entrar, mas eu amo você como pessoa. Eu sei que você é uma pessoa incrível, então eu imagino que esse TCC (por favor, me mande para eu ler) vai ser espetacular. (E5)

Adorei a entrevista. Achei que tocou em pontos muito bons da parte de empreendedorismo. Obrigada, primo. Gostei muito! (E7)

\subsubsection{Título do estudo}

O título abordado é bem especial que eu queria que o mundo pudesse ouvir essa entrevista, para mudar percepções, cabeças de muitas pessoas e pra incentivar jovens a empreender, porque eu acho que dentro de si, todo mundo tem uma coisinha que queira investir, mas não consegue por uma falta de conhecimento ou até mesmo de uma palavra amiga. (E2)

Eu gostei do título, porque ele vai fazer outras pessoas a se interessarem em empreender. Alguém vai se identificar com a minha história ou de outra pessoa que você entrevistou e vai se libertar também. (E6)

Eu me via como uma lojinha, porém, agora, consigo ver algo a mais, pois despertou meus sonhos e objetivos. Me deu ânimo pra continuar lembrar do que motiva. (E4)

O título é top! É muito bom! Eu acho que é importante você abordar um assunto dessa classe, porque eu acho que é até esquecida no sentido de "como esse cara chegou ali? Como ele fez? Quais os caminhos que ele percorreu? Por onde ele passou?" Quando você faz uma análise de quem tem recurso, você sabe que ele fez multiplicar. A gente que é dessas classes C, D \& E, a gente tem de lutar muito para ter recurso, condição e vivência. Coisas que a gente não tem. Você tocou no assunto de pessoas que vieram dessas classes populares e tentaram empreender e conseguiram, por isso é muito bacana você abordar esse assunto. (E8)

Os jovens oriundos de camadas populares que querem empreender é porque, normalmente, a vivência de um jovem da camada popular é de 
uma família que vem de bastante trabalho, luta e de esforço. Ele vem de uma família que se esforça pra dar pra ele o mínimo, que é um pouco de educação. Ele vê o esforço da família, para que ele tenha algo melhor. Então, ele quer empreender pra poder tanto retribuir o que nos foi dado e o que a gente possa dar para os nossos filhos coisas melhores que a gente teve. (E1)

Eu achei interessante, porque o que motiva é a necessidade. Se você vem de um berço de ouro que é herdeiro, você vai até querer fazer, seguir o legado, mas se você tem a necessidade da fome, de matar a fome da sua família, você precisa sair de área de riscos... n situações que vai querer empreender. Eu acho que a nossa geração está com muita mente aberta. Não é porque você fez 18 anos e terminou a escola e ter que procurar emprego assalariado. Não! Por que que eu não posso ser empresário? Por que eu não posso investir? Por que eu não posso ter o meu próprio negócio? Gente, vamos mudar isso aí. Não é porque eu venho de uma classe menor que eu tenho que me submeter a uma classe assalariada. Eu acho isso ótimo! Tem que pensar mesmo grande. Tem que sair daquela caixinha. Já faz o estereótipo da gente. Às vezes, é falta de oportunidade e de estudo. (E10)

Eu achei muito interessante, porque ele vai ali na comunidade, nas pessoas que têm menos recursos. Começar é muito difícil. Eu ainda tive uma ajudinha do meu pai e do meu marido, mas tem gente que não tem ajuda nenhuma e tem um mundo de sonhos. Por isso, eu acho super necessária à sua entrevista pra esclarecer quem não conhece essa realidade e entender esse mundo dessas pessoas que estão aqui e que querem também o seu lugar ao sol. Eu achei que o tema é super necessário, principalmente, para o atual momento do país. (E3)

Apesar de já estar enraizado que as pessoas de baixa renda empreendem por questões financeiras, mas nem sempre é só isso. As pessoas veem a oportunidade de ter algo que elas sabem fazer muito bem para juntar com a parte de ter um retorno financeiro. Então, eu acho que vai valer muito essa pesquisa de campo para gente, para entender melhor o que levam esses jovens a empreender. (E5) 


\section{Conclusão}

O presente estudo visa investigar os fatores motivacionais que levam os jovens da Geração Y e, pertencentes às camadas populares da cidade do Rio de Janeiro, a empreender. Para isso, foi adotada uma metodologia de natureza qualitativa estruturada em um roteiro de perguntas para 10 jovens millennials, empreendedores e oriundos de baixa renda.

O objetivo foi levantar informações através de suas experiências de vida e por meio de seus relatos em suas trajetórias empreendedoras, adicionalmente, procurou-se compreender o quanto a motivação, por vários motivos alheios a esses jovens, é um aspecto importante para decidir abrir um negócio.

Observou-se que não há como generalizar as características geracionais e empreendedoras, quando o aspecto da desigualdade social interfere na vida desses jovens. Há alguns aspectos em comum, tais como o fato de querer tudo o mais breve possível e querer trabalhar com o que gosta e se identifica. Eles almejam a liberdade de não trabalhar para alguém e, consequentemente, a autonomia em suas atividades desempenhadas, que o seu empreendimento proporciona.

Analisando os resultados, observou-se que um número expressivo dos entrevistados empreendeu por necessidade, mostrando-se um importante fator de motivação para esses jovens, como solução para lidar com as dificuldades, com a falta de empregabilidade, de renda e como a única solução possível de sobrevivência. Porém, ao mesmo tempo, é possível refletir que a necessidade financeira que motiva o jovem a abrir seu próprio negócio pode ser a mesma que gera uma oportunidade em empreender, pois o desespero pela sobrevivência o obriga a perceber uma oportunidade de usar suas habilidades em um nicho de mercado.

Cabe ressaltar que alguns entrevistados percebiam o empreendedorismo como algo muito distante da realidade vivenciada por eles e, que ao buscar conhecimento, seja na faculdade ou ter atitude de arriscar a empreender, a percepção desse abismo começa a mudar. Esse fato corrobora com o que Baron (2004) diz que o conhecimento adquirido é a base para o reconhecimento de uma oportunidade para empreender. 
É interessante saber que para $60 \%$ dos jovens entrevistados, o empreendedorismo é a principal atividade e fonte de renda. Além disso, um dado curioso adquirido pelas entrevistas demonstra que da amostra entrevistada, $80 \%$ dos "Yrs" não possuíam como primeira opção o desejo de empreender. Vários motivos foram relatados, tais como a vontade em ser militar; juíza; a família ter a cultura do serviço público; a vontade de ter um emprego CLT; terminar os estudos e concluir a graduação; não ter capital para investir e sobreviver para pagar as contas.

Os millennials nasceram com a internet, logo é relevante saber o papel das redes sociais para qualquer empreendimento hoje em dia, principalmente, o que elas representaram na pandemia do coronavírus. O Instagram foi a ferramenta mais citada por eles. Por isso, é perceptível o quanto a inovação tecnológica derrubou barreiras de comunicação e tornou-se a nova forma para divulgar e impulsionar as vendas dos seus produtos e serviços. Pode-se inferir que seja melhor que o marketing boca a boca.

Com a presente pesquisa, pode-se observar que ao escolher empreender, aspectos como acreditar nas suas convicções; ter sangue nos olhos; investir em si e em algo que saiba fazer bem; realizar um sonho fazendo algo que ama; organização e persistência; ter a consciência de que ao empreender pode dar certo ou não; tentar não se frustrar ou levar a frustração da melhor forma possível se algo der errado; ter a liberdade de acordar a hora que desejar; o impacto que o empreendimento pode causar nos funcionários e clientes; liberdade financeira; saber que empreender não é fácil e que demanda tempo, dedicação, estudo e saber as angústias dos clientes são exemplos relatados pelos entrevistados.

Afinal, o que motiva os jovens empreendedores de classes populares pertencentes à Geração Y?

Esses jovens possuem trajetórias profissionais distintas, pois a herança social impacta profundamente nas suas vidas. Logo, as experiências vivenciadas por eles influenciam nas perspectivas de seus futuros, fazendo com que os seus interesses sejam moldados de acordo com as suas possibilidades (SILVA, 2018).

Por mais que o autor do presente estudo tenha limitado a dois fatores motivacionais como a necessidade financeira e a oportunidade, não seria justo fechar os olhos para os inúmeros aspectos motivacionais que nascem em cada coração desses jovens. Embora, no estudo, tenha se confirmado que o maior 
motivador continua sendo a necessidade de renda, essas estrelas possuem inúmeros sonhos motivacionais, tais como gerar a empresa dos sonhos; alcançar a realização pessoal; ajudar a construir um futuro melhor para os filhos; libertar as ideias e sonhos da gaiola, que seria o trabalho em forma de CLT; gerar um impacto social nas vidas das pessoas e na economia do país; acreditar no sonho da mãe e empreender junto.

É inegável o fato de que a trajetória empreendedora não foi fácil. É um caminho árduo com inúmeros obstáculos e dificuldades a serem enfrentadas. Eles sabem que o país não oferece suporte necessário e ideal como forma de apoio. As variáveis políticas e econômicas, na maioria das vezes, os desestimulam com a falta de apoio do poder público, inúmeras taxações e burocracias. A falta de tempo para conciliar a vida pessoal, faculdade e até mesmo um emprego que ajuda na renda familiar os deixam preocupados. Uma pandemia no meio do caminho da trajetória empreendedora faz lembrar do Mundo VUCA deixando o futuro mais incerto e nebuloso.

Porém, as frases que este autor mais ouviu durante a pesquisa de campo sobre esses jovens estrelas são: "Não desistir." "Persista!" "Não é fácil!" "Sempre vai ter alguém que vai dizer que seu trabalho não vai dar certo, mas eu tenho que ter fé e arriscar."

Por isso, o autor deste presente Trabalho de Conclusão de Curso de Administração da Pontifícia Universidade Católica do Rio de Janeiro, jovem, da Geração Y e pertencente às camadas populares da cidade do Rio de Janeiro arrisca dizer que, talvez, a maior motivação desses jovens sejam eles mesmos. No final do dia, são eles que lutam por eles. São eles que acreditam em si próprios. Sempre foram eles o protagonista de suas histórias e o grande motivador para empreender.

\subsection{Sugestões e recomendações para futuras pesquisas}

O autor do presente estudo sugere a possibilidade de discussão em salas de aula de empreendedorismo sobre como se originou a motivação de jovens de baixa renda, porque muitas das vezes, eles são esquecidos na margem da sociedade. Sugere-se também a realização de novas pesquisas com o intuito de averiguar como se deu toda a trajetória do jovem empreendedor da comunidade ou da periferia através dos seus relatos para aprofundar os conhecimentos sobre os 
empreendedores oriundos de classes menos favorecidas. Como desdobramentos futuros, os achados deste estudo não podem parar por aqui. É indispensável para a sociedade que novos estudos, pelo Brasil, sejam feitos com uma amostra maior, porém contendo o perfil desses jovens. Eles existem e precisam ser ouvidos.

Assim, concluo com a resposta de uma entrevistada respondendo a importância do título do presente estudo:

Eu acredito que o impacto social de você estar estudando esse tema, ele já abre um leque, uma discussão tão válida, tão grandiosa, que eu vou começar a chorar. Justamente, pela falta de apoio, de incentivo, de informação. Quando eu falo de apoio é porque a gente não sabe nem por onde começar. A informação é tudo. E o TCC é nada mais que uma pesquisa que você está defendendo, buscando. Então, essa pesquisa, com certeza, vai quebrar visões limitadas de inúmeras pessoas que nunca pararam para questionar esse tema, que nem eu parei para questionar, logo eu que me enquadro. Eu ouço muito que as pessoas se inspiram em mim, mas eu nunca parei pra pensar quem são essas pessoas que se inspiram em mim. E hoje, só de você estra falando, eu para pra pensar da nossa geração, o quanto as pessoas admiram por não ter tido a coragem de saber que é possível fazer o que eu faço, por falta de informação ou medo. A pessoa quando está informada vai buscar ainda mais, então ela vai saber que o TCC foi algo pesquisado ela vai entender e vai se colocar naquela situação

É um impacto social enorme, é um legado que você vai deixar pra ciência social e para vários estudos posteriores e eu vou ter uma honra enorme de ter participado. Que você vai desenvolver um trabalho no seu ramo com uma expertise maior e muito mais aprofundada que vai te possibilitar a ser um profissional que vai te fazer mudanças sociais na vida das pessoas e eu vou ter muito orgulho de presenciar daqui a alguns anos lembrar que a gente estava aqui falando sobre o seu TCC. Eu me sinto lisonjeada de te conhecer e de participar dessa etapa, pois a gente precisa realmente de pessoas oriundas de classes baixas vindo da periferia que modifique a estrutura do sistema que não é feito pra gente como a gente e que as próximas gerações não tenham que passar pelo que a gente passou.

(Vanessa chaves, jovem empreendedora da Geração Y pertencente às camadas populares da cidade do Rio de Janeiro, 2021) 


\section{Referências Bibliográficas}

ALSOP, R. The trophy kids grow up: how the millennial generation is shaking up the workplace. São Francisco: Jossey-Bass, 2008

BARON, R. A. Opportunity Recognition: a cognitive perspective. Lally school of management \& technology, Academy of management best conference paper, 2004

BENAVIDES ESPINOSA, M. D. M. \& GARCIA, I. S. El estudiante universitario como emprendedor: un análisis cualitativo desde la perspectiva de los diferentes agentes implicados. 2004. Disponível em: . Acesso em: 31/outubro/2021

CARVALHO, G. Empreendedorismo no Brasil: apoiadores, oportunidades e permanências. Administradores.com, Paraíba, 17 de abril de 2019. Disponível em: < https://administradores.com.br/artigos/empreendedorismo-no-brasil-apoiadores-oportunidades-epermanencias>. Acesso em: 26 de junho de 2019

DORNELAS, J. C. A. Empreendedorismo: transformando ideias em negócios. 3. ed. Rio de Janeiro: Elsevier, 2008. GARCIA, L. F. Conduta ou personalidade de um empreendedor. Empreendedor. São Paulo, n. 169, p. 76, nov. 2008

EUROPEAN ECONOMY: EUROPEAN COMMISSION - 2003. Disponível em: <European Economy. 6/2003. The EU economy 2003 review. (europa.eu)> Acesso em 23/outubro/2021.

GLOBAL ENTREPRENEURSHIP MONITOR. Empreendedorismo no Brasil - 2005: relatório nacional. Curitiba: IBQP, 2006. Disponível em: <https:/ibqp.org.br/wpcontent/uploads/2016/10/Empreendedorismo-no-Brasil-2006.pdf>. Acesso em09/novembro/2021.

GLOBAL ENTREPRENEURSHIP MONITOR. Empreendedorismo no Brasil - 2018: relatónio nacional. Curitiba: IBQP, 2019. Disponível em: <Livro Empreendedorismo no Brasil - web compactado.pdf(ibqp.org.br) $>$ Acesso em 01/novembro/2021.

LEITE, E. O Fenômeno do Empreendedorismo. Recife, Bagaço, 2000.

LEZANA, A. G. R. Fundamentos do empreendedorismo. Florianópolis: UFSC/PPGEP. Proferido em aula, out. 2004.

LEZANA, A. G. R. \& TONELLI, A. O comportamento do empreendedor. In: DE MORI, F. (Org.). Empreender: identificando, avaliando e planejando um novo negócio. Florianópolis: ENE, 2004.

MAXIMIANO, A. C. A. Administração para empreendedores: fundamentos da criação e da gestão denovos negócios. São Paulo: Pearson Prentice Hall, 2006.

MINUZZI, J.; GRAPEGGIA, M. As habilidade do empreendedor no ciclo de vida organizacional. In: SEMINÁRIO REGIONAL DE ATUALIZAÇÃO EMPRESARIAL, 2., 2004, Pato Branco. Anais... Pato Branco, CEFET, 2004 
IXDORFF, J. \& SOLOMON, G. Role of opportunity recognition in teaching entrepreneurship. Proceedings of the 2005 50th World Conference of ICSB. Crystal Gateway Marriott - Washington, DC-15-18 June 2005. http://www.usasbe.org

Pinto, Mariana. "Somos o futuro da nação": expectativas profissionais dos jovens brasileiros das camadas populares. Rio de Janeiro, 2017. Número de páginas p. 35. Trabalho de Conclusão de Curso - Departamento de Administração. Pontifícia Universidade Católica do Rio de Janeiro.

SÁ, P.F.; LEMOS, A.H.C.; CAVAZOTTE, F.S.C.N. Expectativas de Carreira na Contemporaneidade: O que Querem os Jovens Profissionais? Revista ADM.MADE, v. 18, n. 2, p. 8-27, maio/agosto. 2014.

SÁ, J. G. S.; LEMOS, A. H. C. Sentido do Trabalho: Análise da Produção Científica Brasileira. Revista ADM.MADE, v. 21,n. 3,p. 21-39, 2017

SANTOS, P.C.F.; MINUZZI, JOSIANE; GARCIA, J. R. \& LEZANA, A. G. R. Empreender por oportunidade versus necessidade: um estudo com empreendedores catarinenses. XXVII Encontro nacional de engenharia de produção. ENEGEP 2007.

SARASON, Y.; DEAN, T. \& DILLARD, J. F. Entrepreneurship as the nexus of individual and opportunity: a structuration view. Journal of Business Venturing, v. 21, p. 286-305, 2006.

Silva, A. L. R. Expectativas profissionais dos jovens brasileiros das camadas populares. Relatório final PIBIC/2018.

SMOLA, K.; W.; SUTTON, C.D. Generational differences: revisiting generational work values for thenew millennium. Journal of Organizational Behavior, v. 23, n. 4, 2002.

VASCONCELOS, K.C.A. et al. A geração Y e suas âncoras de carreira. Gestão.Org, v. 8, p. 226$244,2010$.

Veja. Taxa de empreendedorismo no Brasil chega a 38\%. Rio de Janeiro, 2019 Disponível em: < https://veja.abril.com.br/economia/dino/taxa-de-empreendedorismo-no-brasil-chega-a-38/>. Acesso em: 28 de junho. 2019

Veloso, E. F. R. (2012). É possível negar a existência da geração Y no Brasil? Revista Organização \& Sociedade

ZEMKE, R.; RAINES, C.; FILIPCZAK, B. Generations at work: Managing the clash of veterans, boomers, xers, and nexters in your workplace. Nova York: AMACOM, 2000 


\section{Apêndice}

Roteiro de Entrevista

Bom dia/tarde/noite!

Gostaria de lhe agradecer pela sua disponibilidade, tempo e carinho por conceder sua entrevista para ajudar no meu trabalho de conclusão de curso da faculdade.

Sou estudante de administração da PUC-RIO. O tema do estudo é "Motivação empreendedora" e o título se chama: "O que motiva os jovens oriundos de camadas populares a empreender?"

Gostaria de ressaltar que não há respostas certas ou erradas, pois eu só quero ouvir sua opinião, experiência e conhecimento sobre seu papel como empreendedor (a).

A entrevista é totalmente anônima, logo somente eu saberei as suas informações. Digo isso, porque eu precisarei gravar em formato de áudio a nossa entrevista para posteriormente transcrevê-la com o intuito de realizar uma melhor análise das informações.

Vamos começar?

1. Qual o seu nome, idade, profissão, raça/cor, filhos, bairro onde mora, estado civil, escolaridade e faixa de renda familiar?

2. Qual o nome do seu empreendimento? Ano de criação? Qual o ramo do seu negócio?

3. O que o/a motiva a empreender?

4. Sempre foi a sua primeira opção empreender?

5. Quando você começou a trabalhar no ramo do seu empreendimento?

6. Essa é a sua principal atividade/renda? Se não, qual seria a outra atividade principal?

7. Quais eram as suas expectativas em relação ao empreendedorismo no brasil antes de empreender?

8. Em que medidas essas expectativas foram confirmadas depois que você começou a empreender?

9. Fale-me como tem sido sua vivência no empreendedorismo? (Aspectos positivos).

10. Fale-me como tem sido sua vivência no empreendedorismo? (Aspectos negativos) 
11. Você teve algum momento que passou por alguma dificuldade na sua trajetória empreendedora?

12. Que aspecto você considera mais importante ao escolher empreender?

13. Você acompanha as notícias pelo mundo?

14. Qual foi o impacto da pandemia no seu negócio?

15. Após um ano e meio do início da pandemia, quais as principais mudanças que você percebeu no seu empreendimento?

16. Se você pudesse falar, qual seria o maior dilema vivenciado desde quando decidiu empreender?

17. Qual o seu diferencial?

18. Faz sentido as palavras "necessidade" e "oportunidade" no empreendedorismo? E para você, faz sentido na sua trajetória empreendedora? Qual delas ou nenhuma teve um peso maior para você?

19. Você se arrepende de ter escolhido o empreendedorismo? Por quê?

20. Em uma frase, o que seria o conceito de empreendedorismo para você?

21. Você gostaria de deixar seu ponto de vista sobre a entrevista e o título abordado? Só para relembrar que o título é: "o que motiva os jovens oriundos de camadas populares a empreender?" 